\title{
Persistensi Laba Dimediasi Corporate Social Responsibility pada Perusahaan Manufaktur Sektor Insustri Konsumsi Makanan dan Minuman di Bursa Efek Indonesia
}

\author{
Afdil Malik Ibrohim ${ }^{1}$, Darmanysah ${ }^{2}$, Muhammad Yusuf ${ }^{3}$ \\ 1,2,3 Universitas Pancasila, Jakarta, Indonesia
}

\author{
INFO ARTIKEL \\ JEL Classification : \\ Q56, M41
}

Keywords :

cash flow volatility, sales volatility, leverage, firm size, corporate social responsibility (CSR), earning persistence

\begin{abstract}
This research is aimed to examine andfind out empirical evidence of the influence of Cash Flow Volatility, Sales Volatility, Leverage, Firm size, Corporate Social Responsibility (CSR) on earnings persistence and the influence of Cash Flow Volatility, Sales Volatility, Leverage, Firm size on earnings persistence when mediated by Corporate Social Responsibility (CSR) in manufacturing companies consumer goods industry sectors food and beverages listed on the Indonesia Stock Exchange period 2011-2015. The sampling method used is purposive sampling, of the population of in manufacturing companies consumer goods industry sectors food and beverages that exist, would have taken some samples were selected based on certain criteria. Data were tested by means of the classic assumption by using multiple regression analysis techniques (multiple regression) using SPSS 22 for windows. The results show that Cash Flow Volatility, Sales Volatility, Firm size, Corporate Social Responsibility (CSR) partially have no influence significant on Earning persistence. Leverage has significant effect to earnings persistence. Cash Flow Volatility on earnings persistence when mediated by Corporate Social Responsibility (CSR) have significant effect. Sales Volatility, Firm size, Leverage on earnings persistence when mediated by Corporate Social Responsibility (CSR) have not significant effect. The tests are based on a confidence level of $95 \%$, and an error rate of $5 \%$.
\end{abstract}

\begin{abstract}
ABSTRAK
Penelitian ini bertujuan untuk menguji dan mengisi bukti empiris pengaruh Volatilitas Arus Kas, Volatilitas Penjualan, Leverage, Ukuran Perusahaan, Tanggung Jawab Sosial Perusahaan (CSR) terhadap persistensi laba dan pengaruh Volatilitas Arus Kas, Volatilitas Penjualan, Leverage, Perusahaan ukuran pada persistensi pendapatan ketika dimediasi oleh Corporate Social Responsibility (CSR) di perusahaan manufaktur sektor industri barang konsumsi makanan dan minuman yang terdaftar di Bursa Efek Indonesia periode 2011-2015. Metode pengambilan sampel yang digunakan adalah purposive sampling, dari populasi perusahaan manufaktur sektor industri barang konsumsi makanan dan minuman yang ada, pasti diambil beberapa sampel yang dipilih berdasarkan kriteria tertentu. Data diuji
\end{abstract}


dengan menggunakan asumsi klasik dengan menggunakan teknik analisis regresi berganda (multiple regression) menggunakan SPSS 22 for windows. Hasil penelitian menunjukkan bahwa Volatilitas Arus Kas, Volatilitas Penjualan, ukuran Perusahaan, Corporate Social Responsibility (CSR) secara parsial tidak memiliki pengaruh yang signifikan terhadap Earning Persistence. Leverage berpengaruh signifikan terhadap persistensi laba. Volatilitas Arus Kas terhadap persistensi laba ketika dimediasi oleh Corporate Social Responsibility (CSR) memiliki pengaruh yang signifikan. Volatilitas Penjualan, ukuran Perusahaan, Leverage pada persistensi laba ketika dimediasi oleh Corporate Social Responsibility (CSR) tidak memiliki pengaruh yang signifikan. Tes didasarkan pada tingkat kepercayaan 95\%, dan tingkat kesalahan $5 \%$.

\section{Pendahuluan}

Perusahaan manufaktur sektor industry makanan dan minuman memiliki peranan penting dalam pertumbuhan ekonomi Indonesia. Sektor tersebut menjadi satu dari bebera sektor yang di jadikan prioritas pemerintah dalam mendorong industri sebagai penggerak ekonomi Indonesia. Pertumbuhan Ekonomi Indonesia mengalami fluktuasi perlambatan dari tahun 2011 sampai tahun 2015. (sumber : kemenkeu dan BI). Hal ini, berdampak langsung pada Pertumbuhan Perusahaan manufaktur sektor industry makanan dan minuman Indonesia. Pada tahun 2011, pencapaian laba sebesar $14 \%$, tahun 2012 turun diangka 10\% dan tahun 2013 mengalami penurunan laba yang sangat signifikan, yaitu pencapaian laba hanya sebesar 99\% dari tahun 2012. Sedangkan pada tahun 2014, naik menjadi 7\% dan tahun 2015, $2 \%$. Beberapa perusahaan mengalami kerugian dan tidak melaporkan laporan keuangannya secara lengkap pada periode tahun 2011 - 2015. Perusahaan yang masih bertahan memerlukan modal, supaya bisa bertahan hidup dan dapat bersaing dengan perusahaan lain.

Informasi mengenai jumlah laba, harta, hutang dan pengungkapan CSR, yang mencerminkan ukuran perusahaan, tingkat hutang, arus kas dan penjualan yang terdapat dalam laporan hasil dari pertanggungjawaban perusahaan dalam laporan kinerja operasi di perusahaan merupakan sinyal manajemen mengenai kemampuan perusahaan menghasilkan laba yang persisten.
Konstruksi persistensi laba tidak dapat diobservasi secara langsung, namun hanya dapat diobservasi dan diukur melalui proksi atau atribut-atribut yang melekat di dalam laba itu sendiri (Fanani 2010).

Determinan persistensi laba diantaranya yaitu : volatilitas arus kas, volatilitas penjualan, tingkat hutang dan ukuran perusahaan. Faktor pertama yang berpengaruh terhadap persistensi laba adalah volatilitas arus kas. volatilitas merupakan fluktuasi atau pergerakan yang bervariasi yang terjadi dari satu periode ke periode lain. Jika arus kas berfluktuasi tajam atau volatilitas arus kas tinggi maka akan sangat sulit untuk memprediksi arus kas di masa yang akan datang. Volatiitas arus kas yang tinggi menunjukkan persistensi laba yang rendah (Dechow dan Dichev, 2002). Penelitian sebelumnya mengenai pengaruh volatilitas arus kas terhadap persistensi laba telah dilakukan Fanani (2010) dan Rahmadahani (2016) yang menyimpulkan bahwa voaltilitas arus kas berpengaruh negatif terhadap persistensi laba. Hasil penelitian tersebut tidak konsiten dengan penelitian Sulastri (2014) yang menyimpulkan bahwa Votalitas arus kas berpengaruh positif namun tidak signifikan terhadap persistensi laba.

Selanjutnya volatilitas penjualan juga dapat mempengaruhi persistensi laba. Volatilitas penjualan dapat mempengaruhi persistensi laba karena volatilitas penjualan menunjukkan fluktuasi lingkungan operasi dan penyimpangan aproksimasi yang besar, dimana volatilitas penjualan yang rendah akan 
dapat memprediksi aliran kas dimasa yang akan datang. Namun jika tingkat volatilitas penjualan tinggi, maka persistensi laba tersebut akan rendah, karena laba yang dihasilkan akan mengandung banyak gangguan (noise). Penelitian sebelumnya mengenai pengaruh volatilitas penjualan telah dilakukan oleh Rahmadhani (2016), Fanani (2010); Penelitian-penelitian tersebut menyimpulkan volatilitas penjualan berpengaruh negatif terhadap persistensi laba. Hasil penelitian ini bertolak belakang dengan penelitian Sulastri (2014), bahwa Volatilitas penjualan berpengaruh positif namun tidak signifikan terhadap persistensi laba dan Shenjaya, Juniarti (2016) , menyatakan bahwa Volatilitas penjualan tidak berpengaruh signifikan terhadap persistensi laba.

Selanjutnya tingkat utang. Perusahaan dalam memperoleh laba tidak dapat terlepas dari sumber modal perusahaan guna membiayai kegiatan operasi perusahaan agar dapat terus berkembang usahanya dan menghasilkan laba. Salah satu sumber modal perusahaan adalah utang. Ketika perusahaan mempunya tingkat utang yang tinggi perusahaan akan meningkatkan persistensi laba dengan tujuan untuk mempertahankan kinerja perusahaan yang baik dimata investor maupun calon investor. Dengan kinerja yang maksimal diharapkan kreditor memiliki kepercayaan terhadap perusahaan, tetap mengucurkan dana, dan perusahaan akan memperoleh kemudahan dalam proses pembayaran kewajibannya. Penelitian mengenai pengaruh tingkat utang terhadap persistensi laba telah dilakukan oleh Fanani (2010), Ramadhani (2016), Fitriana dan Fadhila (2016) menyatakan tingkat utang berpengaruh signifikan positif terhadap persistensi laba. Penelitian ini bertolak belakang dengan penelitian yang dilakukan, Sulastri (2014), Tingkat hutang berpengaruh negative namun tidak signifikan terhadap persistensi laba. Kusuma dan Sadjiarto (2014), menyatakan bahwa tingkat utang tidak berpengaruh signifikan terhadap persistensi laba.

Ukuran perusahaan yang tercermin pada laporan keuangan merupakan salah satu ukuran untuk menilai suatu perusahaan. Pada dasarnya perusahaan besar yang telah mencapai tahap kedewasaan mencerminkan bahwa perusahaan relative lebih setabil dan lebih mampu menghasilkan laba dibandingkan perusahaan kecil. Perusahaan yang setabil biasanya tingkat kepastian untuk memperoleh laba sangat tinggi, karena sumber daya yang tinggi. Sebaliknya, bagi perusahaan kecil kemungkinan laba yang diperoleh juga belum stabil karena tingkat kepastian laba lebih rendah karena sumber daya kecil. Hasil penelitian Septavita (2016), bahwa ukuran perusahaan berpengaruh signifikan terhadap persistensi laba. Begitu juga penelitian yang dilakukan oleh Dwi dan I.G.A.M (2015), bahwa ukuran perusahaan berpengaruh positif pada persistensi laba. Hal tersebut bertentangan dengan penelitian yang telah dilakukan oleh Shenjaya dan Juniarti (2016), bahwa ukuran perusahaan tidak berpengaruh terhadap persistensi laba.

Perusahaan dalam menjalankan aktivitas usahanya tidak hanya beroperasi untuk kepentingan perusahaan saja, tetapi juga harus dapat bermanfaat bagi para stakeholder-nya seperti konsumen, pemegang saham, masyarakat, kreditor, pemerintah, dan pihak lain. Tanggung jawab sosial perusahaan atau Corporate Social Responsibility (CSR) adalah suatu bentuk komitmen perusahaan kepada para stakeholder-nya dalam mempertanggungjawabkan dampak dari aktivitas operasi perusahaan. Pemerintah Indonesia memberikan perhatian terhadap aktivitas CSR melalui Undang-undang Nomor 40 tahun 2007. Pasal 66 ayat 1 menyatakan bahwa laporan pelaksanaan tanggung jawab sosial perusahaan merupakan hal-hal yang harus dimuat dalam laporan tahunan perusahaan. Menurut Laksmana dan Yang (2009) stakeholder theory menyatakan bahwa perusahaan memiliki kontrak dengan stakeholder dan dalam kontrak tersebut terdapat value berupa reputasi perusahaan. Reputasi yang baik di mata stakeholder tentu dapat mengurangi risiko perusahaan seperti tuntutan dari pelanggan ketika perusahaan gagal melindungi lingkungan sekitar. Pandangan tersebut sesuai dengan penelitian yang dilakukan oleh Rosdwianti, Dzulkirom dan Zahrahh (2016), bahwa corporate social responbility berpengaruh signifikan terhadap profitabilitas. Akan tetapi Hal tersebut bertentangan dengan penelitian yang dilakukan oleh Shenjaya dan Juniarti (2016), 
Tedjosukmono dan Juniarti (2016), bahwa CSR tidak berpengaruh terhadap persistensi laba.

Berdasarkan fenomena yang terjadi dan gap penelitian terdahulu, maka peneliti terdorong untuk melakukan pengujian kembali untuk mengetahui faktor apa saja yang mempengaruhi persistensi laba, dengan mengembangkan penelitian-penelitian terdahulu. Penelitian ini dengan judul "Determinan Persistensi Laba, Ketika Dimediasi Oleh Corporate Social Responsibility Pada Perusahaan Manufaktur Sektor Insustri Konsumsi Makanan Dan Minuman Di Bursa Efek Indonesia Periode 2011 - 2015", karena Manufaktur sektor Industri makanan dan minuman, yang terkena dampak langsung akibat naik turunnya pertumbuhan ekonomi.

\section{Telaah Teori dan Pengembangan Hipotesis}

\section{Signaling theory}

Signaling Theory menjelaskan bahwa informasi yang dikemukakan pihak manajemen kepada pihak luar merupakan isyarat atau sinyal bagi pasar. Dimana isyarat atau sinyal merupakan tindakan manajemen perusahaan, yang memberikan petunjuk bagi investor tentang bagaimana manajemen memandang prospek perusahaan. Informasi mengenai jumlah pendapatan, asset, kewajiban dan pengungkapan CSR, yang mencerminkan ukuran perusahaan, tingkat hutang, arus kas operasi dan penjualan yang terdapat dalam laporan hasil dari pertanggungjawaban manajemen atau pihak internal atas kinerjanya di perusahaan merupakan sinyal manajemen mengenai kemampuan perusahaan menghasilkan laba yang persisten.

\section{Teori Stakeholder (Stakeholder Theory)}

Teori stakeholder mengatakan bahwa perusahaan bukanlah entitas yang hanya beroperasi untuk kepentingan sendiri namun harus memberi manfaat bagi stakeholder. Fenomena seperti ini terjadi karena adanya tuntutan dari masyarakat akibat negative externalities yang timbul serta ketimpangan sosial yang terjadi (Harahap dalam Hadi, 2011:93). Perusahaan hendaknya memperhatikan kepentingan stakeholder, karena mereka adalah pihak yang mempengaruhi baik secara langsung maupun tidak langsung atas aktivitas perusahaan serta kebijakan yang diambil dan dilakukan perusahaan. Berdasarkan pada asumsi dasar teori stakeholder, perusahaan tidak dapat melepaskan diri dengan lingkungan sosial sekitarnya. Perusahan perlu menjaga legitimasi stakeholder serta menempatkannya dalam kerangka kebijakan dan pengambilan keputusan, sehingga dapat mendukung dalam pencapaian tujuan perusahaan, yaitu stabilitas usaha dan jaminan going concern (Adam dalam Hadi, 2011:94).

\section{Persistensi Laba}

Persistensi laba merupakan salah satu indikator untuk mengukur kualitas laba dan dapat didefinisikan sebagai kemampuan laba perusahaan pada periode ini untuk mencerminkan laba di periode berikutnya dimana laba ini memiliki sifat yang berulang, tidak fluktuatif dan berkelanjutan (Dechow dan Dichev, 2002). Persistensi laba dapat digunakan untuk mengukur keberhasilan bisnis, menilai kinerja dan menghitung kompensasi untuk manajemen, menentukan pemberian dividen kepada shareholder, mengambil keputusan terutama terkait hutang / investasi jangka panjang dan dapat memberikan informasi risiko (Fanani, 2010).

\section{Volatilitas Arus Kas}

Volatilitas arus kas adalah derajat penyebaran arus kas atau indeks penyebaran distribusi arus kas perusahaan. Jika arus kas berfluktuasi tajam maka akan sulit untuk memprediksi arus kas di masa yang akan datang. Volatilitas arus kas dapat mempengaruhi persistensi laba. Di dalam suatu kegiatan usaha, pasti arus kas akan menunjukkan angka yang berbeda-beda setiap periodenya. Namun, angka tersebut tidak mungkin terpaut jauh dalam suatu periode singkat. Bila terjadi hal dimana arus kas operasional suatu perusahaan berubah drastis dalam waktu singkat secara terus-menerus, maka ini dapat menjadi indikasi arus kas tersebut tidak merefleksikan keadaan operasional perusahaan sebenarnya. Hal ini akan turut berdampak pada laba perusahaan, yang berarti laba perusahaan juga tidak menunjukkan keadaan yang sebenarnya, dan tidak dapat dijadikan dasar untuk 
memprediksi laba perusahaan pada periode mendatang (Fanani, 2010).

\section{Volatilitas Penjualan}

Volatilitas penjualan merupakan derajat penyebaran atau indeks penyebaran distribusi penjualan perusahaan (Dechoe dan Dichev, 2002). volatilitas penjualan dapat menjadi indikasi fluktuasi lingkungan operasi, dan kecendrungan perusahaan menggunakan estimasi. Volatilitas penjualan yang tinggi memiliki kesalahan estimasi yang lebih besar pada informasi penjualan di lingkungan operasi (Dechow dan Dichev, 2002). Aliran kas yang dihasilkan dari aktivitas penjualan otomatis akan berujung pada laba perusahaan, sehingga volatilitas penjualan juga akan berdampak langsung terhadap volatilitas laba itu sendiri. Apabila volatilitas penjualan tinggi maka volatilitas laba perusahaan juga akan cenderung tinggi sehingga persistensi laba atau kestabilan laba menjadi rendah.

\section{Tingkat Utang}

Rasio yang dipakai untuk mengukur tingkat utang perusahaan adalah rasio Leverage, Leverage merupakan rasio yang menghitung seberapa jauh dana yang disediakan oleh kreditur juga sebagai rasio yang membandingkan total utang terhadap keseluruhan total aset suatu perusahaan. Sawir, (2005). Investor melihat sebuah perusahaan dengan aset yang tinggi, tetapi resiko utang yang tinggi pula, maka akan berpengaruh terhadap keputusan investor untuk melakukan investasi pada perusahaan tersebut. Besarnya tingkat utang akan menyebabkan perusahaan meningkatkan persistensi laba dengan tujuan untuk mempertahankan kinerja perusahaan yang baik dimata investor. Dengan kinerja perusahaan yang baik diharapkan kreditor tetap memiliki kepercayaan terhadap perusahaan, tetap mengucurkan dana, dan perusahaan akan memperoleh kemudahan dalam proses pembayaran kewajibannya.

\section{Ukuran Perusahaan}

Ukuran perusahaan merupakan jumlah total hutang dan ekuitas perusahaan yang akan berjumlah sama dengan total aktiva. Pada dasarnya perusahaan dapat terbagi dalam dua kategori yaitu perusahaan besar dan perusahaan kecil. Sudarsono (2005). Berdasarkan uraian tentang ukuran perusahaan diatas maka dapat disimpulkan bahwa ukuran perusahaan adalah merupakan suatu indikator yang dapat menunjukan kondisi atau karateristik perusahaan dimana terdapat beberapa parameter yang dapat digunakan untuk menentukan ukuran (besar kecilnya) suatu perusahaan, seperti banyaknya jumlah karyawan yang digunakan perusahaan untuk melakukan kegiatan aktivitas operasi perusahaan, total penjualan perusahaan yang dicapai oleh perusahaan dalam suatu periode, jumlah aktiva yang dimiliki dan jumlah saham yang beredar.

\section{Corporate Social Responsibility}

Definisi pertanggungjawaban sosial perusahaan atau Corporate Sosial Responsibility adalah mekanisme bagi suatu organisasi untuk secara sukarela mengintegrasikan perhatian terhadap lingkungan dan sosial ke dalam operasinya dan interaksinya dengan stakeholders yang melebihi tanggung jawab organisasi di bidang hukum. Pertanggungjawaban sosial diungkapkan di dalam laporan yang disebut sustainability reporting. Sustainability reporting adalah pelaporan mengenai kebijakan ekonomi, lingkungan dan sosial, pengaruh dan kinerja dan produk di dalam konteks pembangunan berkelanjutan (sustainable development). Darwin (2004) dalam Anggraini (2006).

\section{Hipotesis Penelitian :}

H1 : Volatilitas Arus Kas berpengaruh signifikan terhadap Persistensi Laba.

$\mathrm{H} 2$ : Volatilitas Penjualan berpengaruh signifikan terhadap Persistensi Laba.

H3 : Tingkat Utang berpengaruh signifikan terhadap Persistensi Laba.

H4 : Ukuran Perusahaan berpengaruh signifikan pada persistensi laba.

H5 : Corporate Social Responsibility (CSR) berpengaruh signifikan terhadap Persistensi Laba.

H6 : Votalitas Arus Kas berpengaruh signifikan terhadap persistensi laba, ketika dimediasi oleh Corporate Social Responsibility.

H7 : Volatilitas penjualan berpengaruh signifikan terhadap Persistensi laba, ketika dimediasi oleh Corporate Social Responsibility. 
H8 : Tingkat utang berpengaruh signifikan terhadap persistensi laba, ketika dimediasi Corporate Social Responsibility.

H9 : Ukuran Perusahaan berpengaruh signifikan terhadap Persistensi Laba, ketika dimediasi oleh Corporate Social Responsibility.

\section{Kerangka Pemikiran Path Analisis}

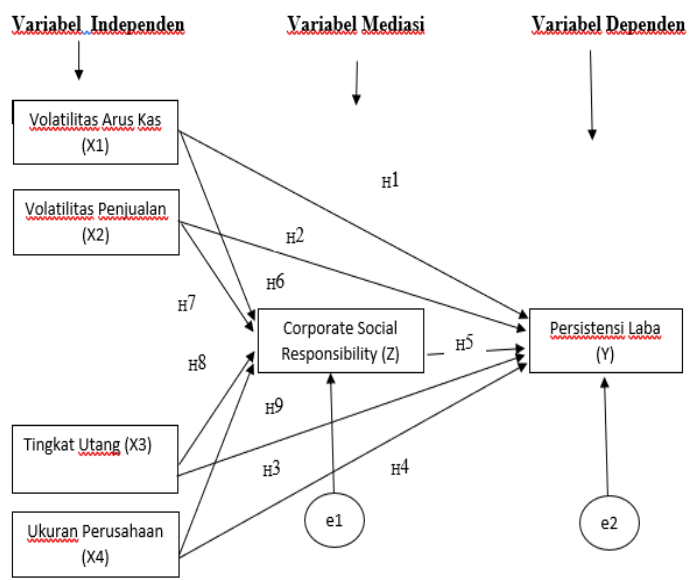

Jenis Penelitian ini, penelitian Kuantitatif dengan menggunakan path analisis. Penelitian menggunakan path analisis karena metode path analisis sesuai dengan apa yang menjadi permasalahan dalam penelitian ini. Objek dalam penelitiannya adalah perusahaan manufaktur sektor industri konsumsi makanan dan minuman yang terdaftar di BEI tahun $2011-2015$.

\section{Definisi Operasional dan Pengukuran}

Pada penelitian ini terdapat enam variabel yang akan digunakan, yaitu empat variabel bebas, satu variabel terikat dan satu variable pemediasi, variable bebas adalah variabel yang mempengaruhi variabel lain, variabel terikat adalah variabel yang dipengaruhi oleh variabel lain, sedangkan variable pemediasi adalah variable yang mempengaruhi hubungan antara variable independen dengan variable dependen menjadi hubungan yang tidak langsung.

\section{Persistensi laba (PL), Variabel Dependen (Y)}

Variabel dependen dalam penelitian ini adalah persistensi laba. Persistensi laba merupakan salah satu alat ukur kualitas laba yang ditunjukkan dengan adanya kesinambungan laba, sehingga laba yang persisten cenderung stabil di setiap periode (Purwanti, 2010). Persistensi laba akuntansi diukur menggunakan koefisien regresi antara laba akuntansi periode sekarang dengan laba akuntansi yang lalu (Romasari, 2013). Skala data yang digunakan adalah rasio, dengan rumus rasio, dengan rumus:

$$
X \text { it }=\alpha+\beta X \text { it }-1+\varepsilon
$$

Dimana :

$\alpha=$ Konstanta

$\mathrm{X}$ it $=$ Laba perusahaan $\mathrm{i}$ tahun $\mathrm{t}$

$\mathrm{X}$ it-1 $=$ Laba perusahaan $\mathrm{i}$ tahun $\mathrm{t}-1$

$\beta=$ Koefisien hasil regresi (peristensi laba)

$\varepsilon \quad=$ Komponen eror dalam model

Apabila persistensi laba akuntansi $(\beta)>1$ hal ini menunjukkan bahwa laba perusahaan adalah high persisten. Apabila persistensi laba $(\beta)>0$ hal ini menunjukkan bahwa laba perusahaan tersebut persisten. Sebaliknya, persistensi laba $(\beta) \leq 0$ berarti laba perusahaan fluktuatif dan tidak persisten.

\section{Variabel Intervening}

Variabel intervening yang digunakan dalam penelitian ini adalah Corporate Social Responsibility. Pengungkapan diukur dengan proksi Corporate Social Responsibility Indeks (CSRI) berdasarkan indikator Global Reporting Initiative (GRI). CSRI dinilai dengan membandingkan jumlah pengungkapan yang dilakukan oleh perusahaan dengan jumlah pengungkapan yang disyaratkan dalam GRI G3 yang meliputi 79 item pengungkapan. Jika item diungkapkan oleh perusahaan maka perusahaan akan mendapat skor 1 , tetapi jika perusahaan tidak mengungkapkan item tersebut, perusahaan akan mendapatkan skor nol. Semakin tinggi skor yang didapatkan oleh sebuah perusahaan menandakan pelaksanaan CSR dalam perusahaan sudah bagus. Perhitungan CSRI berdasarkan indikator Global Reporting Initiative (GRI) dirumuskan sebagai berikut:

$$
\mathrm{CSR}=\frac{\text { Jumlah item yang diungkapkan perusahaan }}{\text { Item pengungkapan yang seharusnya }}
$$

\section{Volatilitas Arus Kas}

Volatilitas merupakan fluktuasi atau pergerakan yang bervariasi yang terjadi dari 
satu periode ke periode lain. Pengukuran volatilitas arus kas menurut Fanani (2010) Dechow dan Dichev (2002) adalah standar deviasi aliran kas operasi dibagi dengan total aset. Volatilitas arus kas adalah standar deviasi aliran kas operasi dibagi dengan total aktiva. Data variabel volatilitas arus kas merupakan data rata-rata selama lima tahun Di ukur dengan menggunakan rumus:

$$
\frac{\sigma(\mathrm{CFO}) \mathrm{t}}{\text { Total Aktiva jt }}
$$

Dimana:

CFOjt $=$ Aliran Kas operasi perusahaan $\mathrm{j}$ tahun $\mathrm{t}$ Total Aktiva $\mathrm{jt}=$ Total Aktiva Perusahaan $\mathrm{j}$ tahun $\mathrm{t}$

\section{Volatilitas Penjualan}

Volatilitas penjualan adalah standar deviasi penjualan dibagi dengan total aktiva. data variable volatilitas penjualan ini merupakan rata-rata selama lima tahun (Fanani, 2010). Data variable volatilitas penjualan merupakan rata-rata selama lima tahun Berikut rumus pengukuran volatilitas penjualan:

$$
\frac{\sigma \text { (Penjualan selama } 5 \text { tahun jt) }}{\text { Total Aktiva jt }}
$$

Dimana:

Penjualan $\mathrm{jt}=$ Penjualan perusahaan $\mathrm{j}$ mulai tahun $\mathrm{t}$ Total Aktiva $\mathrm{jt}=$ Total Aktiva perusahaan $\mathrm{j}$ tahun $\mathrm{t}$

\section{Tingkat Utang}

Tingkat hutang merupakan penggunaan dana yang disertai biaya tetap. Sedangkan menurut Weston and Copeland (2009) menyebutkan tingkat hutang atau disebut juga leverage faktor adalah rasio nilai buku seluruh hutang terhadap total aktiva. Pengukuran tingkat hutang diperoleh dari total hutang dibagi dengan total aset Tingkat utang diukur dengan total utang dibagi dengan total aset. Data variabel tingkat utang merupakan data rata-rata selama lima tahun. Di ukur dengan menggunakan rumus:

Total utang jt

Total aktiva jt

Dimana:

Total utang $\mathrm{jt}=$ Total utang perusahaan $\mathrm{j}$ tahun $\mathrm{t}$ Total aktiva $\mathrm{jt}=$ Total aktiva perusahaan $\mathrm{j}$ tahun $\mathrm{t}$

\section{Ukuran Perusahaan}

Sesuai dengan penelitian Persada dan Dwi (2008), proksi untuk mengukur ukuran perusahaan (size) diperoleh dengan rumus:

$$
\text { Size }=\text { Ln (Total Aset) }
$$

\section{Metode Penelitian}

Analisis jalur merupakan perluasan dari analisis regresi linear berganda, atau analisis jalur digunakan untuk menganalisis pola hubungan antar variabel dengan tujuan untuk mengetahui pengaruh langsung maupun tidak langsung seperangkat variabel bebas terhadap variabel terikat. Pada dasarnya koefisien jalur adalah koefisien regresi yang distandarkan. Berikut adalah perumusan substruktur path analisis pada peneitian ini.

Substruktur 1 :

$\mathrm{Z}=\mathrm{PZ} \mathrm{X}_{1}+\mathrm{PZ} \mathrm{X}_{2}+\mathrm{PZ} \mathrm{X}_{3}+\mathrm{PZ} \mathrm{X}_{4}+\epsilon_{1}$

\section{Substruktur 2 :}

$$
\begin{aligned}
\mathrm{Y}= & \mathrm{PY} \mathrm{X}_{1}+\mathrm{PY} \mathrm{X}_{2}+\mathrm{PY} \mathrm{X}_{3}+\mathrm{PY} \mathrm{X}_{4}+\mathrm{PY} \mathrm{Z} \\
& +\epsilon_{2}
\end{aligned}
$$

Keterangan:

$\mathrm{Y}=$ Persistensi Laba

$\mathrm{Z}=$ Corporate Social Responsibility (CSR)

$\mathrm{X}_{1} \quad=$ Volatilitas Arus Kas

$\mathrm{X}_{2} \quad=$ Volatilitas Penjualan

$\mathrm{X}_{3} \quad=$ Tingkat Hutang

$\mathrm{X}_{4} \quad=$ Ukuran Perusahaan

$\mathrm{e} \quad=$ error

Objek Pada penelitian ini adalah perusahaan manufaktur sektor industri konsumsi makanan dan minuman yang terdaftar di BEI periode 2011 - 2015. Sampel diambil 11 perusahaan manufaktur sektor industri konsumsi makanan dan minuman yang dipilih berdasarkan kriteria tertentu (Purposive Sampling) pada tahun 2011-2015 atau selama 5 tahun terakhir. Sampel yang dipilih pada penelitian ini adalah perusahaan Manufaktur sektor industri konsumsi makanan dan minuman yang sudah tercatat selama 5 tahun berturut-turut di Bursa Efek Indonesia untuk periode 2011-2015 dan menerbitkan laporan keuangan secara lengkap.

Uji normalitas digunakan untuk mengetahui, apakah distribusi nilai residual 
normal atau tidak. Melihat pada tabel 4.2 pada kolom Unstandardized Residual, nilai signifikansi (Asymp. Sig. 2-tailed) bernilai 0,177 . Syarat yang harus dipenuhi agar data berdistribusi normal nilai signifikansi tersebut lebih besar dari 0,05 (error), maka dapat disimpulkan bahwa nilai residual tersebut berdistribusi normal.

Uji Multikolinearitas bertujuan, menguji apakah model regresi ditemukan adanya korelasi antar variabel independen (Ghozali, 2001: 64) Berdasarkan Uji Multikolinearitas diketahui nilai Tolerance untuk variabel Volatilitas Arus kas adalah sebesar 0,782; Tolerance untuk volatilitas Penjualan sebesar 0,851; Tolerance untuk Tingkat utang 0,882. Tolerance untuk Ukuran Perusahaan sebesar 0,553 dan Tolerance dari variabel CSR sebesar 0,514; Semua nilai Tolerance dari masing-masing variabel bebas adalah lebih dari 0,1 . Sedangkan untuk nilai VIF dapat diketahui bahwa nilai VIF untuk variabel volatilitas arus kas, volatilitas penjualan, tingkat utang dan ukuran perusahaan dan CSR berturut-turut adalah sebesar 1,278, 1,175, 1,133, 1,808 dan 1,945. Nilai VIF untuk semua variabel independen tersebut kurang dari 10. Dengan melihat nilai Tolerance dan nilai VIF maka dapat disimpulkan pada model regresi tidak ditemukan adanya hubungan multikolinearitas pada model regresi.

Uji Heteroskedastisitas yaitu keadaan dimana terjadi ketidaksamaan varian dari residual untuk semua pengamatan pada model regresi. Berdasarkan Uji Heteroskedastisitas, bahwa titik-titik menyebar secara acak, tidak membentuk suatu pola tertentu yang jelas, serta tersebar di atas dan dibawah angka nol pada sumbu Y. Dapat disimpulkan bahwa model regresi dalam penelitian ini bebas dari heteroskedastisitas.

Uji Autokorelasi bertujuan, menguji apakah dalam suatu model regresi linier ada korelasi antara kesalahan penganggu pada periode $\mathrm{t}$ dengan kesalahan pada periode $\mathrm{t}-1$ (sebelumnya). (Ghozali, 2001:67). Berdasarkan Uji Autokorelasi, bahwa nilai Durbin-Watson sebesar 1,786. Dari tabel DW dengan nilai signifikansi 0,05 dan jumlah data $(\mathrm{n})=55$, serta $\mathrm{k}=5 \quad$ (jumlah variabel independen) diperoleh nilai DU sebesar 1,7681 dan nilai dl sebesar 1,3743. Dikarenakan DW lebih besar dari DU dan lebih kecil dari 5-DU $(5-1,7681=3,23)$, maka dapat disimpulkan tidak terjadi autokorelasi.

\section{Hasil Penelitian dan Pembahasan}

Substruktur 1 :

$$
\mathrm{Z}=\mathrm{PZX}_{1}+\mathrm{PZ} \mathrm{X}_{2}+\mathrm{PZ} \mathrm{X}_{3}+\mathrm{PZ} \mathrm{X}_{4}+\epsilon_{1}
$$

\section{Koefisien Determinasi}

Tabel 4.7 Hasil Uji Regresi

Model Summary

\begin{tabular}{l|r|r|r|r|}
\hline Model & \multicolumn{1}{|c|}{ R } & R Square & $\begin{array}{c}\text { Adjusted R } \\
\text { Square }\end{array}$ & $\begin{array}{c}\text { Std. Error of } \\
\text { the Estimate }\end{array}$ \\
\hline 1 &, $697^{\mathrm{a}}$ &, 486 &, 445 &, 04857 \\
\hline
\end{tabular}
a. Predictors: (Constant), Size, Turtang, Volpen, Volkas
Sumber : Data diolah

Koefisien determinasi merupakan koefesien yang menentukan sebesrapa besar kemampuan seluruh variabel independen dalam menjelaskan varian varian variabel dependen. Secara sederhana koefesien determinasi dihitung dengan menguadratkan koefisien korelasi ( $\mathrm{R}$ ). $R$ Square $\left(R^{2}\right)$ menunjukkan koefisien determinasi. $R^{2}$ sama dengan 0 , maka tidak ada sedikitpun prosentase sumbangan pengaruh yang diberikan variable independen terhadap variabel dependen. Sebaliknya $R^{2}$ sama dengan 1, maka persentase sumbangan pengaruh yang diberikan variabel independen terhadap variabel dependen adalah sempurna. Adjusted $R$ Square adalah $R$ Square yang telah disesuaikan. Adjusted $R$ Square dapat mengukur sumbangan pengaruh jika dalam regresi menggunakan lebih dari dua variabel independen.

Nilai R2 dalam penelitian ini adalah 0.486 atau sebesar $48,6 \%$, hal ini menunjukan bahwa variabel dalam penelitian hanya memiliki kontribusi sebesar $48.6 \%$, sedangkan $51.4 \%$ dipengaruhi oleh variabel variabel lain yang tidak terdapat dalam penelitian ini. 


\section{Uji F}

\begin{tabular}{|c|c|c|c|c|c|c|}
\hline \multicolumn{7}{|c|}{$\begin{array}{c}\text { Tabel } 4.8 \\
\text { ANOVA }\end{array}$} \\
\hline \multicolumn{2}{|c|}{ Model } & $\begin{array}{l}\text { Sum of } \\
\text { Squares }\end{array}$ & Df & $\begin{array}{l}\text { Mean } \\
\text { Square }\end{array}$ & $\mathrm{F}$ & Sig. \\
\hline \multirow[t]{3}{*}{1} & Regression & ,111 & 4 &, 028 & 11,809 &, $000^{\circ}$ \\
\hline & Residual & ,118 & 50 & ,002 & & \\
\hline & Total & ,229 & 54 & & & \\
\hline \multicolumn{7}{|c|}{ a. Dependent Variable: CSR } \\
\hline \multirow{2}{*}{\multicolumn{7}{|c|}{ b. Predictors: (Constant), }} \\
\hline & & & & & & \\
\hline
\end{tabular}

Uji $\mathrm{F}$ digunakan untuk menguji signifikansi secara simultan, pengaruh antara signifikansi volatilitas arus kas, volatilitas penjualan , tingkat utang dan ukuran perusahaan terhadap corporate social responsibility. Untuk menilai signifikansi variabel tersebut dapat dilihat dari nilai $\mathrm{F}$ hasil statistik. Apabila nilai signifikansi $\mathrm{F}<0.05$ maka dapat dikatakan model substruktur 1 , signifikan. Dalam penelitian ini nilai $F$ statistic adalah 0.0000 , oleh karena itu dapat dikatakan model substruktur 1 , berpengaruh signifikan.

\section{Uji T}

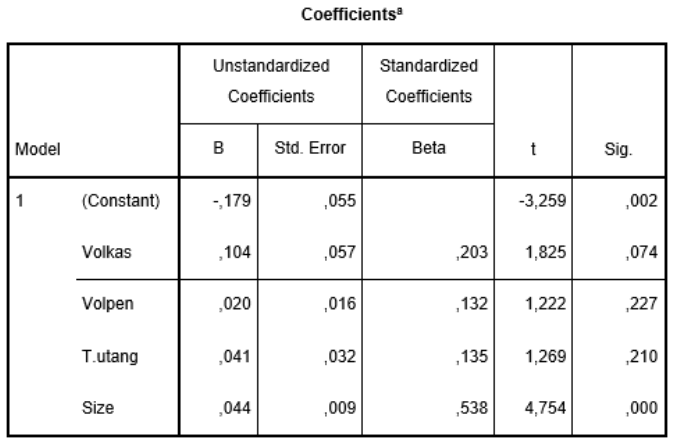

a. Dependent Variable: CSR

Sumber: Data diolah

Untuk menguji signifikansi dari nilai koefisien regresi semua variabel independen dalam persamaan regresi, dapat dilihat dari nilai $t$ dan nilai signifikansinya. Hal ini dilakukan untuk menguji apakah secara parsial masing masing variabel independen memiliki pengaruh yang signifikan terhadap variabel dependen.Dalam hal ini, untuk mengetahui apakah secara parsial variabel volatilitas arus kas, volatilitas penjualan, tingkat utang dan ukuran perusahaan berpengaruh secara signifikan terhadap corporate social responcibility. Pengujian dalam penelitian ini menggunakan tingkat signifikansi 0,05 .

Berdasarkan tabel atas, nilai koefisien regresi volatilitas arus kas terhadap Corporate social responsibility adalah sebesar 0,203 dan dengan nilai signifikansi 0,074 lebih besar dari 0,05 (tingkat kesalahan). Sedangkan volatilitas penjualan 0,132 dan dengan nilai signifikansi 0,227 lebih besar dari 0,05 (tingkat kesalahan). Tingkat utang 0,135 dan dengan nilai signifikansi 0,210 lebih besar dari 0,05 (tingkat kesalahan). Ukuran perusahaan adalah sebesar 0,538 dan dengan nilai signifikansi 0,000 lebih kecil dari 0,05 (tingkat kesalahan). Hal ini menunjukan bahwa, hanya variabel ukuran perusahaan yang berpengaruh signifikan terhadap corporate social responsibility.

Substruktur 2 :

$$
\begin{aligned}
Y= & P y X_{1}+P y X_{2}+P y X_{3}+P y X_{4}+ \\
& \text { Py } X_{5}+\epsilon 2
\end{aligned}
$$

\section{Koefisien Determinasi}

Tabel 4.10 Hasil Uji Regresi Model Summary

\begin{tabular}{|l|r|r|r|r|}
\hline Model & \multicolumn{1}{|c|}{$\mathrm{R}$} & $\mathrm{R}$ Square & \multicolumn{1}{c|}{$\begin{array}{c}\text { Adjusted } \mathrm{R} \\
\text { Square }\end{array}$} & $\begin{array}{c}\text { Std. Error of the } \\
\text { Estimate }\end{array}$ \\
\hline 1 &, $555^{\mathrm{a}}$ &, 308 &, 238 &, 55146 \\
\hline
\end{tabular}

Predictors: (Constant), CSR, Jutang, Volpen, Volkas, Size Sumber. Data diolah

Berdasarkan tabel 4.10 diatas dapat terlihat nilai R2 dalam penelitian persamaan substruktur 2 ini adalah 0,308 atau sebesar 30,8\%, hal ini menunjukkan bahwa variabel dalam penelitian ini memiliki kontribusi sebesar 30,8 \%, sedangkan $69,2 \%$ dipengaruhi oleh variabel - variabel lain yang tidak terdapat dalam penelitian ini. 


\section{Uji F}

Tabel 4.11 Hasil Uji Regresi

ANOVA $^{\text {a }}$

\begin{tabular}{|c|c|c|c|c|c|c|}
\hline \multicolumn{2}{|c|}{ Model } & $\begin{array}{l}\text { Sum of } \\
\text { Squares }\end{array}$ & Df & $\begin{array}{l}\text { Mean } \\
\text { Square }\end{array}$ & $\mathrm{F}$ & Sig. \\
\hline \multirow[t]{3}{*}{1} & Regression & 6,647 & 5 & 1,329 & 4,372 &, $002^{\mathrm{b}}$ \\
\hline & Residual & 14,901 & 49 &, 304 & & \\
\hline & Total & 21,549 & 54 & & & \\
\hline
\end{tabular}

a. Dependent Variable: PL

b. Predictors: (Constant), CSR, Tutang, Volpen, Volkas, Size

Dalam penelitian ini nilai F statistik adalah sebesar 0,000 dapat terlihat pada tabel 4.11, oleh karena itu dapat dikatakan model substruktur 2 dalam penelitian ini memperoleh hasil yang signifikan.

Uji T

Tabel 4.12 Hasil Uji Regresi

Coefficients $^{\mathrm{a}}$

\begin{tabular}{|c|c|c|c|c|c|c|}
\hline \multirow[b]{2}{*}{ Model } & & \multicolumn{2}{|c|}{$\begin{array}{l}\text { Unstandardized } \\
\text { Coefficients }\end{array}$} & \multirow{2}{*}{\begin{tabular}{|c|}
$\begin{array}{c}\text { Standardized } \\
\text { Coefficients }\end{array}$ \\
Beta \\
\end{tabular}} & \multirow[b]{2}{*}{$t$} & \multirow[b]{2}{*}{ Sig. } \\
\hline & & B & $\begin{array}{l}\text { Std. } \\
\text { Error }\end{array}$ & & & \\
\hline \multirow[t]{6}{*}{1} & (Constant) &,- 993 & .687 & & $-1,447$ &, 154 \\
\hline & Volkas &, 055 &, 665 &, 011 &, 083 & 934 \\
\hline & Volpen & 274 & , 186 & 190 & 1,474 & 147 \\
\hline & Tutang &, 788 &, 371 & ,269 & 2,127 &, 038 \\
\hline & Size & ,224 &, 126 & 284 & 1,777 & 082 \\
\hline & CSR & 866 & 1,606 &, 089 &, 540 &, 592 \\
\hline
\end{tabular}

a. Dependent Variable: PL

Sumber: Data diolah

Berdasarkan tabel di atas, diketahui nilai koefisien regresi dari volatilitas arus kas terhadap Persistensi laba adalah sebesar 0,11 dan dengan nilai signifikansi 0,934 lebih besar dari 0,05 (tingkat kesalahan). SedangkanVolatilitas penjualan sebesar 0,190 dan dengan nilai signifikansi 0,147 lebih besar dari 0,05 (tingkat kesalahan). kemudian Tingkat utang sebesar 0,269 dan dengan nilai signifikansi 0,038 lebih kecil dari 0,05 (tingkat kesalahan). Kemudian Ukuran perusahaan sebesar 0,284 dan dengan nilai signifikansi 0,082 lebih besar dari 0,05 (tingkat kesalahan). Corporate social responsibility sebesar 0,089 dan dengan nilai signifikansi 0,592 lebih besar dari 0,05 (tingkat kesalahan). Sehingga dapat disimpulkan bahwa hanya tingkat hutang yang berbengaruh signifikan terhadap persistensi laba.

\section{Pembahasan}

Untuk memudahkan analisis dari penelitian ini maka penulis merangkum seluruh hasil penelitian dalam satu tabel, dalam tabel 4.6 di bawah ini :

\section{Tabel 4.6 Rekapitulasi Hasil Uji Model}

\begin{tabular}{|c|c|c|c|c|c|}
\hline \multicolumn{2}{|c|}{ Persamaan } & Koefisien & $\begin{array}{l}\text { Uji Signifikansi } \\
\text { Variabel } \\
\text { (t-Statistic) }\end{array}$ & $R^{2}$ & $\begin{array}{c}\text { Uji Model } \\
(F \text {-statistic) })\end{array}$ \\
\hline $\begin{array}{c}\text { Tahap } \\
\text { I }\end{array}$ & $\begin{array}{c}\text { Corporate } \\
\text { Social } \\
\text { Responsibility } \\
\text { (CSR) }\end{array}$ & $\begin{array}{l}\text { Pzx1 }=0,203 \\
\operatorname{Pzx}=0,132 \\
\operatorname{Pzx} 3=0,135 \\
\operatorname{Pzx} 4=0,538 \\
\in 1=0.514\end{array}$ & $\begin{array}{l}\text { Vol. Arus Kas }=0,074 \\
\text { Vol. Penjualan }=0,227 \\
\text { Tingkat Utang }=0,210 \\
\text { Ukuran Perusahaan } \\
=0,000\end{array}$ & 0,486 & 0,000 \\
\hline $\begin{array}{l}\text { Tahap } \\
\text { II }\end{array}$ & $\begin{array}{l}\text { Persistensi } \\
\text { Laba }\end{array}$ & $\begin{array}{l}\text { Pyx } 1=0,011 \\
\text { Pyx2 }=0,190 \\
\text { Pyx3 }=0,260 \\
\text { Pyx } 4=0,519 \\
\text { PyZ }=0,089 \\
\epsilon 2=0.692\end{array}$ & 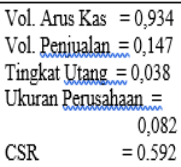 & 0,308 & 0,002 \\
\hline
\end{tabular}

\section{Pengaruh Volatilitas arus kas terhadap persistensi laba.}

Tabel substruktur 2 di atas, diketahui nilai dari variabel volatilitas arus kas terhadap variabel Persistensi laba adalah sebesar 0,11 dengan nilai signifikansi 0,934 lebih besar dari 0,05 (tingkat kesalahan). Hal ini menunjukkan bahwa variabel volatilitas arus kas tidak berpengaruh signifikan terhadap persistensi laba. Dari hasil di atas menunjukkan bahwa tinggi dan rendahnya volatilitas arus kas pada perusahaan manufaktur sektor industri konsumsi makanan dan minuman yang terdaftar di BEI periode 2011 - 2015, tidak berpengaruh terhadap persistensi laba. Dan bertentangan dengan teori yang menyatakan bahwa; Volatiitas arus kas yang tinggi menunjukkan persistensi laba yang rendah (Dechow dan Dichev, 2002). Hasil penelitian tersebut konsiten dengan penelitian Sulastri (2014) yang menyimpulkan bahwa Votalitas arus kas berpengaruh positif namun tidak signifikan terhadap persistensi laba.

\section{Pengaruh Volatilitas penjualan terhadap persistensi laba.}

Tabel substruktur 2 di atas, dapat diketahui nilai dari volatilitas penjualan terhadap Persistensi laba adalah sebesar 0,190 dan dengan nilai signifikansi 0,147 lebih besar 
dari 0,05 (tingkat kesalahan). Dari hasil tersebut menunjukkan bahwa pada perusahaan manufaktur sektor industri konsumsi makanan dan minuman yang terdaftar di BEI periode 2011 - 2015, tinggi dan rendahnya volatilitas penjualan tidak berpengaruh terhadap persistensi laba. Dan bertentangan dengan teori yang menyatakan bahwa, Apabila volatilitas penjualan tinggi maka volatilitas laba juga akan cenderung tinggi sehingga persistensi laba atau kestabilan laba menjadi rendah. Hasil penelitian ini sesuai dengan penelitian Shenjaya, Juniarti (2016), bahwa Volatilitas penjualan tidak berpengaruh signifikan terhadap persistensi laba.

\section{Pengaruh Tingkat utang terhadap persistensi laba.}

Tabel substruktur 2 di atas, dapat diketahui nilai dari variabel Tingkat Utang terhadap Persistensi laba adalah sebesar 0,269 dan dengan nilai signifikansi 0,038 lebih kecil dari 0,05 (tingkat kesalahan). Hal ini menunjukkan bahwa tingkat utang berpengaruh signifikan terhadap persistensi laba. Besarnya tingkat utang akan memotivasi perusahaan untuk meningkatkan persistensi laba dengan tujuan untuk mempertahankan kinerja perusahaan yang baik dimata penanam modal. Dengan kinerja yang baik diharapkan kreditor atau calon kreditor memiliki kepercayaan terhadap perusahaan. kreditor tetap mengucurkan dananya dan calon kreditor akan mengucurkan dananya dengan yakin dan memiliki rasa aman dalam berinvestasi. Perusahaanpun akan mengalami kemudahan dalam proses pembayaran kewajibannya. Hasil penelitian ini sesuai dengan penelitian yang dilakukan oleh oleh Fanani (2010), Ramadhani (2016), Fitriana dan Fadhila (2016) menyatakan tingkat utang berpengaruh signifikan positif terhadap persistensi laba.

\section{Pengaruh Ukuran perusahaan terhadap persistensi laba.}

Tabel substruktur 2 di atas, dapat diketahui nilai Ukuran Perusahaan terhadap Persistensi laba, sebesar 0,284 dan dengan nilai signifikansi 0,082 lebih besar dari 0,05 (tingkat kesalahan). Hal ini menunjukkan bahwa pada perusahaan manufaktur sektor industri konsumsi makanan dan minuman yang terdaftar di BEI periode 2011 - 2015, besar kecilnya perusahaan tidak memberikan pengaruh signifikan terhadap persistensi laba perusahaan. Besarnya perusahaan tidak menjamin perusahaan memiliki persistensi laba yang baik, disebabkan karena tidak semua perusahaan yang besar mampu mengolah aktivitas operasinya dan sumber dayanya yang besar dengan baik sehingga kinerja perusahaannya juga rendah yang akan berdampak pada laba perusahaan menjadi tidak persisten. Perusaan kecil akan berusaha untuk melaksanakan meningkatkan aktifitas operasinya dengan baik agar tetap eksis dan akan berusaha semaksimal mungkin untuk menjalankan sumberdaya yang ada dengan tujuan untuk memperoleh laba.

\section{Pengaruh Corporate social responsibility (CSR) terhadap persistensi laba.}

Tabel substruktur 2 di atas, dapat diketahui nilai signifikansi corporate social responsibility terhadap Persistensi laba adalah sebesar 0,089 dan dengan nilai signifikansi 0,592 lebih besar dari 0,05 (tingkat kesalahan). Menunjukkan bahwa variabel CSR tidak berpengaruh signifikan terhadap persistensi laba pada perusahaan manufaktur sektor industri konsumsi makanan dan minuman yang terdaftar di BEI periode 2011 - 2015. Rata-rata tingkat CSR dalam penelitian ini adalah sebesar $16 \%$, yang menunjukan tingkat CSR nya masih relatif rendah sehingga tidak dapat diharapkan untuk meningkatkan reputasi dimata stackholder. Penyaluran CSR hanya pada lingkungan masyarakat social yang masih ada kaitannya dengan perusahaan terkait.

Pengaruh variabel volatilitas arus kas, volatilitas penjualan, tingkat utang dan ukuran perusahaan terhadap persistensi laba ketika dimediasi oleh corporate social responsibility(CSR)

Diketahui pengaruh langsung volatilitas arus kas terhadap Persistensi laba adalah sebesar 0.011 , dan pengaruh mediasi sebesar 0,018 . Karena pengaruh langsung lebih kecil dari pengaruh mediasi maka, pengaruh mediasi oleh corporate social responsibility berpengaruh signifikan pada perusahaan manufaktur sektor industri konsumsi makanan dan minuman yang terdaftar di BEI periode 2011 - 2015. Sedangkan untuk Pengaruh langsung volatilitas penjualan 0.190, tingkat utang 0.269 dan ukuran perusahaan 0.284 dan 
pengaruh tidak langsung berturut turut, 0.011, 0.012 dan 0.047 . Karena pengaruh langsung lebih besar dari pengaruh mediasi, maka dapat disimpulkan bahwa Volatilitas penjualan, tingkat utang dan ukuran perusahaan tidak berpengaruh terhadap persistensi laba ketika dimediasi oleh corporate social responsibility (CSR) pada perusahaan manufaktur sektor industri konsumsi makanan dan minuman yang terdaftar di BEI periode 2011 - 2015. Pengaruh corporate social responsibility sebagai mediasi volatilitas penjualan, tingkat utang dan ukuran perusahaan terhadap persistensi laba tidak terbukti dan hubungan yang sebenarnya adalah hubungan langsung. Bertolak belakang dengan teori Laksmana dan Yang (2009) stakeholder theory menyatakan, bahwa perusahaan memiliki kontrak dengan stakeholder dan dalam kontrak tersebut terdapat value berupa reputasi perusahaan. Reputasi yang baik di mata stakeholder tentu dapat mengurangi risiko perusahaan seperti tuntutan dari pelanggan ketika perusahaan gagal melindungi lingkungan sekitar. Tidak terdapatnya pengaruh dari CSR sebagai mediasi volatilitas penjualan terhadap persistensi laba ini dikarenakan oleh beberapa hal. Hasil penelitian ini menunjukan rata-rata tingkat CSR nya adalah $16 \%$, yang menunjukan tingkat CSR nya relatif rendah sehingga tidak dapat diharapkan untuk meningkatkan reputasi perusahaan dimata stackholder dan belum bisa mengurangi sangsi social akibat aktifitas operasi perusahaan. Kemudian CSR di indonesia di atur dalam Undang - Undang no 40 tahun 2007 tentang perseroan terbatas yang hanya mengatur dalam pasal 74 ayat 1 bahwa perusahaan hanya diwajibkan melakukan CSR tanpa ada ketentuan yang jelas bagaimana CSR dilakukan sehingga tujuan belum tercapai. Peraturan dalam undang - undang masih berupa mandatori saja, untuk menghilangkan kewajiban dan tidak ada undang-undang yang mengatur mengeni sangsinya jika perusahaan tidak menerapkan CSR. Penyaluran CSR hanya pada lingkungan masyarakart social yang masih ada kaitannya dengan perusahaan terkait.

\section{Kesimpulan, Keterbatasan dan Implikasi Hasil Penelitian}

Adapun kesimpulan dari penelitian ini adalah;

1. Pengaruh langsung volatilitas arus kas, volatilitas penjualan, ukuran perusahaan dan corporate social responsibility (CSR) tidak signifikan terhadap persistensi laba. Hanya tingkat hutang yang berpengaruh signifikan pada perusahaan manufaktur sektor industry konsumsi makanan dan minuman yang terdaftar di BEI periode $2011-2015$.

2. Volatilitas arus kas terhadap persistensi laba, ketika dimediasi oleh corporate social responsibility (CSR) berpengaruh signifikan. Sedangkan volatilitas penjualan, tingkat utang dan ukuran perusahaan ketika di mediasi CSR tidak berpengaruh signifikan pada perusahaan manufaktur sektor industri konsumsi makanan dan minuman yang terdaftar di BEI periode 2011 - 2015.

Peneliti menyadari adanya keterbatasan yang dimiliki oleh penelitian ini. Adapun keterbatasan penelitian, yaitu : Dalam penelitian ini menggunakan lima variabel independen yaitu volatilitas arus kas, volatilitas penjualan, tingkat utang, ukuran perusahaan dan corporate social responsibility (CSR) dan dapat menjelaskan terhadap persistensi laba jika dilihat dari nilai Adjusted $R$ Square (R2) hanya sebesar 0,308 atau 30,8 dan sisanya 69.2 dijelaskan oleh faktor-faktor lain yang tidak dimasukkan dalam model penelitian ini. Selain itu dalam penelitian ini hanya menggunakan populasi dari perusahaan manufaktur sektor industry konsumsi makanan dan minuman.

\section{Daftar Pustaka}

Rahmadhani, A., \& Hariadi, H. (2016). Pengaruh Book-tax Differences, Volatilitas Arus Kas, Volatilitas Penjualan, Besaran Akrual, dan Tingkat Utang terhadap Persistensi Laba (Studi Empiris pada Perusahaan Aneka Industri yang Terdaftar di Bei Tahun 2010-2014). Jurnal Online Mahasiswa Fakultas Ekonomi Universitas Riau, 3(1), 2163-2176. 
Anggraini, F. R. R. (2006). Pengungkapan informasi sosial dan faktor-faktor yang mempengaruhi pengungkapan informasi sosial dalam laporan keuangan tahunan (Studi empiris pada perusahaan-perusahaan yang terdaftar Bursa Efek Jakarta). Simposium Nasional Akuntansi, 9, 23-26.

Kusuma, B., \& Sadjiarto, R. A. (2014). Analisa pengaruh volatilitas arus kas, volatilitas penjualan, tingkat hutang, book tax gap, dan tata kelola perusahaan terhadap persistensi laba. Tax \& Accounting Review, 4(1), 53

Dechow, P. M., \& Dichev, I. D. (2002). The quality of accruals and earnings: The role of accrual estimation errors. The accounting review, 77(s-1), 35-59.

Dewi, N. P. L., \& Putri, I. A. D. (2015). Pengaruh Book-Tax Difference, Arus Kas Operasi, Arus Kas Akrual, Dan Ukuran Perusahaan Pada Persistensi Laba. EJurnal Akuntansi, 244-260.

Fanani, Z. (2010). Analisis faktor-faktor penentu persistensi laba. Jurnal Akuntansi dan Keuangan Indonesia, 7(1), 109-123.

Ghozali, I. (2006). Aplikasi Analisis Multivariate Dengan Program SPSS. Cetakan Keempat. Semarang: Badan Penerbit Universitas Diponegoro.

GRI, G. R. I. (2002). Global reporting initiative. Sustainability Re-porting Guidelines.

www.globalreporting.org/guidelines/ 062006guidelines.asp.

Hadi, N. (2011). Corporate Social Responsibility edisi Pertama: Graha Ilmu. Yogyakarta. Kusumawati, Citra.

(http://www.idx.co.id ).

Indonesia, I. A. (2010). Pernyataan Standar Akuntansi Keuangan (PSAK) No. 23 (Revisi 2010) tentang Pendapatan. Jakarta : Salemba Empat.

Kementrian Perindustrian Republik Indonesia.

Kementrian Keuangan Republik Indonesia.

Kotler, P., \& Lee, N. (2008). Corporate social responsibility: Doing the most good for your company and your cause. John Wiley $\&$ Sons.

Kurtubi, A., \& Pramiudi, U. (2014). Pengaruh Informasi Arus Kas terhadap Return Saham Perusahaan Studi Kasus Pada Perusahaan Yang Tercatat Di Bei Pada Indeks LQ45. Jurnal Ilmiah Akuntansi Kesatuan, 2(1), 047-058.

Laksmana, I., \& Yang, Y. W. (2009). Corporate citizenship and earnings attributes. Advances in Accounting, 25(1), 40-48.

Fitriana, N., \& Fadhlia, W. (2016). Pengaruh Tingkat Hutang Dan Arus Kas Akrual Terhadap Persistensi Laba (Studi Pada Perusahaan Property And Real Estate Yang Terdaftar di Bursa Efek Indonesia Tahun 2010-2014). Jurnal Ilmiah Mahasiswa Ekonomi Akuntansi, 1(1), 258-272.

Septavita, N., Nasir, A., \& Ilham, E. (2016). Pengaruh Book Tax Differences, Arus Kas Operasi, Tingkat Hutang, Dan Ukuran Perusahaan Terhadap Persistensi Laba (Studi Empiris Pada Perusahaan Manufaktur Yang Terdaftar Di Bei Tahun 2011-2013). Jurnal Online Mahasiswa Fakultas Ekonomi Universitas Riau, 3(1), 1309-1323.

Penman, S. H., \& Zhang, X. J. (2002). Accounting conservatism, the quality of earnings, and stock returns. The accounting review, 77(2), 237-264.

Persada, A. E., \& Martani, D. (2010). Analisis Faktor Yang Mempengaruhi Book Tax Gap dan Pengaruhnya Terhadap Persistensi Laba. Jurnal Akuntansi dan Keuangan Indonesia, 7(2), 205-221.

Purwanti, T. (2010). Analisis pengaruh volatilitas arus kas, besaran akrual, volatilitas penjualan, leverage, siklus operasi, ukuran perusahaan, umur perusahaan, dan likuiditas terhadap kualitas laba (Doctoral dissertation, Universitas Sebelas Maret Surakarta).

Romasari, S. (2013). Pengaruh Persistensi Laba, Struktur Modal, Ukuran Perusahaan dan Alokasi Pajak Antar Periode Terhadap Kualitas Laba (Studi Empiris pada 
Perusahaan Manufaktur yang Terdaftar di BEI). Jurnal Akuntansi, 1(2).

Rosdwianti, Dzulkirom dan Zahrahh, 2016. Pengaruh Corporate social responsibility (CSR) terhadap profitabilitas perusahaan (Studi Pada Sektor Industri Barang Konsumsi Yang Terdaftar Di Bursa Efek Indonesia Periode 2013-2014). Fakultas Ilmu Administrasi Universitas Brawijaya Malang. Jurnal Administrasi Bisnis (JAB) Vol. 38 No.2 September 2016.

Agnes, S. (2005). Analisis kinerja keuangan dan perencanaan keuangan perusahaan. Jakarta: PT. Gramedia Pustaka, 226.

Tedjosukmono, S. D. (2016). Pengaruh Kinerja Corporate Social Responsibility (CSR) Terhadap Persistensi Laba Pada Perusahaan Yang Bergerak Di Sektor Industri Dasar Dan Kimia Di Indonesia. Business Accounting Review, 4(1), 349360.

Shenjaya, S. (2016). Pengaruh Kinerja Corporate Social Responsibility terhadap Persistensi Laba pada Perusahaan yang Bergerak di Sektor Barang Konsumsi dengan Subsektor Farmasi, Kosmetik dan Keperluan Rumah Tangga dan Peralatan Rumah Tangga yang Terdaftar di Bursa
Efek Indone. Business Accounting Review, 4(1), 241-252.

Sugiyono, P. Dr. (2010). Metode Penelitian Kuantitatif, Kualitatif, dan $R \& D$. Bandung: CV Alfabeta.

Sulastri, D. A. (2014). Pengaruh Volatilitas Arus Kas, Volatilitas Penjualan, Besaran Akrual, dan Tingkat Hutang Terhadap Persistensi Laba (Doctoral dissertation, Universitas Negeri Padang).

Terbatas, P. Undang-Undang Republik Indonesia Nomor 40 Tahun 2007 Tentang Perseroan Terbatas Pasal 74, Ayat 1-4.

(http://bapepam.go.id).

Watts, R. L., \& Zimmerman, J. L. (1986). Positive accounting theory. Englewood Cliffs: Prentice-Hall

Mulyono, S. (2006). Statistika Untuk Ekonomi \& Bisnis. Lembaga Penerbit Fakultas Ekonomi Universitas Indonesia, Jakarta.

Wijayanti, H. T. (2006). Analisis Pengaruh perbedaan laba akuntansi dan laba fiskal terhadap persistensi Laba. Akrual, dan Arus Kas. " Simposium Nasional Akuntansi $I X$, Padang. 